\title{
Road Service Levels Analysis at The Economic Centers of Archipelago Regions During the Covid-19 Pandemic
}

\author{
Gaus Abdul ${ }^{*}$, Andartomo Zulfikar ${ }^{2}$, Firsandi Sarbin ${ }^{2}$, Nurrahim Aditya ${ }^{1}$, Aksa Sitti Aminah $^{1}$ \\ ${ }^{1}$ Civil Engineering Department, Faculty of Engineering, 97118 Ternate City, Indonesia \\ 2 Project consultant, CV. Indo Sereang Konsultant, 97118 Ternate City, Indonesia
}

\begin{abstract}
This study aims to analyze a changes of service level in the roads as the center of the economy during the covid-19 pandemic. The flow of traffic crosses and connected at the economic centers the archipelago for 7 days, on weekdays and holidays by 14 hours a day from 07 am to $21 \mathrm{pm}$. Restrictions on activity during the COVID-19 pandemic resulted in a significant reduction in traffic movement in economic areas, this caused by restrictions on activities in the non-essential sector in business centers and the diversion of activities from the office to home. During the COVID-19 pandemic, the level of road service at business centers increased significantly due to, first, the shifting of activities from office to home which had an impact on reducing the movement of vehicles from home to offices and shopping centers at business centers, secondly the decline in other obstacles on road sections which usually arise due to trucks loading and unloading goods and street vendors selling their wares on the roadside, and thirdly due to restrictions on the activities of certain sectors that reduce the movement of people to and from across the business center.
\end{abstract}

Keywords: Covid-19, Archipelago, Level of service, Traffic

\section{Introduction}

The emergence of COVID-19 at the end of 2019 in Wuhan, China has had a huge impact on the whole world. The spread of this virus is very fast and has reached up to 188 countries in less than a year. In addition, it has affected the Indonesian economy in various sectors, such as trade, transportation, and tourism $[1,2]$. All countries in the world seem powerless in the face of the rapid spread of COVID-19. Various attempts have been made to prevent its spread [3], including policies on working from home, maintaining distance, limiting vehicle passengers, and implementing lockdown [4,5]. However, activity restrictions greatly affect changes in the movement of people to and across the business centers.

The number of movements that arise as a result of activities on land use is correlated with vehicular traffic passing through a road segment and is directly proportional to the degree of traffic saturation [6]. Roads that cross or connect economic centers generally have a low level of service when compared to other road segments [7]. Several things that affect road capacity are high side frictions as a result of loading and unloading activities, street vendors, and the high number of pedestrians $[8,9,10]$.
Based on the elaboration above, this study is highly necessary to carry out to find out the level of service of roads leading to and through business centers in an island area during the COVID-19 pandemic by using the 1997 Indonesian Road Capacity Manual (Indonesian: Manual Kapasitas Jalan Indonesia 1997 (MKJI 1997) $[11,12,13]$;

\section{Research Methods and MKJI 1997}

This study presented data based on the fact in the field. The collected data were analyzed further to get a conclusion or new concept about the level of service for roads that pass and go through business centers in an island area during the COVID-19 pandemic. This study began with the collection of literature and secondary data related to the topic examined. In conducting surveys in the field, primary data were collected using traffic volume questionnaires and surveys. This study was conducted in the business center of Ternate. Because this study was carried out during a pandemic, the researchers collected data by following the health protocol set by the government.

Data collection was carried out in several stages. First, it began with the selection and determination of the roads that became the research objects. Second, the researchers conducted the collection of geometric data concerning roads leading to, connecting, and crossing

\footnotetext{
* Corresponding author : gaussmuhammad@gmail.co.id
} 
the business center of Ternate. Third, the researchers carried out data collection regarding traffic data on several selected road sections which were considered to be able to represent the criteria of predetermined road sections, such as roads leading to, connecting, and passing the business center. Fourth, the researchers conducted the recapitulation and processed field survey data using the guidelines of the 1997 Indonesian Road Capacity Manual (Indonesian: Manual Kapasitas Jalan Indonesia 1997 (MKJI 1997)).

\subsection{Traffic Volume and Flow}

Traffic volume is the number of vehicles that pass a certain point of a road segment during a certain time. In this study, data collection was carried out for one week from Monday to Saturday. It was conducted for 14 hours from 7 am to $9 \mathrm{pm}$. The collected volume data was the peak hour volume, which is the number of vehicles that pass a certain point on a road segment for one hour when the largest traffic flow occurs in a day. For analysis purposes, the surveyed vehicles were classified as follows.

a. Light vehicles (LV), consisting of passenger cars, jeeps, sedans, minibusses, pick-ups, and others.

b. Heavy vehicles (HV), consisting of buses and trucks.

c. Motorcycle (MC).

\subsection{Road Capacity Analysis}

Road capacity is the maximum flow through a point on a road that can be maintained per unit hour under certain conditions. For two-lane two-way roads, capacity is divided into two-way flows (two-way combinations). However, for multi-lane roads, flows are separated per direction, while capacity is determined per lane. The basic equation for determining capacity is as follows (MKJI, 1997).

\section{$C=C O x F C W X F C S P X F C S F x F C C S$ (vech/hour) (1)}

Where: $C$ is the capacity (vech/hour); $C o$ is the basic capacity variable (vech/hour); $F C W$ is the width adjustment factor of traffic lane; FCSP is the directional split adjustment factor; $F C S F$ is the side friction adjustment factor; FCCS is the city size adjustment factor.

\subsection{Degree of Saturation}

The degree of saturation (DS) is the ratio of road current to capacity, which is used as the main factor in determining the performance level of intersections and road segments. The DS value indicates the presence or absence of problems on the road segment. The basic equation for determining the degree of saturation is shown in Formula 2.

$$
D S=\frac{Q}{C}
$$

Where: $D S$ is the degree of saturation; $Q$ is traffic flow (vech/hour); $C$ is capacity (vech/hour).

\subsection{Side Frictions}

Side frictions are activities on the roadside that have an impact on traffic performance. Roadside activities often cause conflicts that affect traffic, especially road capacity and speed of urban roads. The side friction category and its weight factor can be seen in Table 1.

Table 1. The weight of side frictions

\begin{tabular}{|l|c|c|}
\hline \multicolumn{1}{|c|}{$\begin{array}{c}\text { Types of Side } \\
\text { Friction Events }\end{array}$} & Symbol & $\begin{array}{c}\text { Weight } \\
\text { Factor }\end{array}$ \\
\hline Pedestrians & PED & 0.5 \\
\hline Parking vehicles & PSV & 1.0 \\
\hline $\begin{array}{l}\text { Vehicles entering } \\
\text { and leaving the } \\
\text { roadside }\end{array}$ & EEV & 0.7 \\
\hline $\begin{array}{l}\text { Slow-moving } \\
\text { vehicle }\end{array}$ & SMV & 0.4 \\
\hline
\end{tabular}

\subsection{Level of Service}

The level of service (LOS) is a unit in measuring the quality of the traffic flow. The LOS can describe the operational conditions of traffic flow and drivers in terms of speed, travel time, comfort, freedom, movement, security, and safety. The value of the LOS may change along with the increase in traffic volume on a road segment and changes in road geometric conditions. The LOS can be used as a parameter concerning the relationship between speed, density, and service level in a traffic flow. The formula for finding out the LOS value is as follows.

$$
L O S=\frac{V}{C}
$$

Where: $L O S$ is the level of service; $V$ is traffic volume (vech/hour); $C$ is the actual capacity (vech/hour).

The quality of road services can be represented using the level of service. The quality of road service is divided into 6 conditions from the best to the worst. It is determined on an interval scale consisting of 6 levels, namely levels A, B, C, D, E, and F.

\section{Results and Discussion}

\subsection{Geometric Data}

The geometric data of roads are data concerning the geometric condition of the examined road segments and represent the characteristics of the road segment. Geometric conditions consist of a situation plan (land use, road markings, and intersections) and road sections (road width and roadside width). The results of measurements and direct visual observations in the field, namely J1. Pahlawan Revolusi (JL1), Jl. Nukila (JL2) and Jl. M. Djabir Sjah (JL3), are as shown in Table 2. JL1 is categorized as a road that passes through business centers that connect residential areas and business centers. Meanwhile, JL2 is categorized as a road that 
connects business centers within the city center. Furthermore, JL3 is categorized as a road that crosses the outskirts of business centers and cities.

Table 2. Weight of Side Frictions

\begin{tabular}{|l|l|c|c|c|}
\hline $\begin{array}{l}\text { Name } \\
\text { of the } \\
\text { Road }\end{array}$ & \multicolumn{1}{|c|}{ Type } & $\begin{array}{c}\text { Road } \\
\text { width } \\
(\mathrm{M})\end{array}$ & $\begin{array}{c}\text { Median } \\
\text { Width } \\
(\mathrm{M})\end{array}$ & $\begin{array}{c}\text { Roadside } \\
\text { Width } \\
(\mathrm{M})\end{array}$ \\
\hline JL1 & $\begin{array}{l}\text { Undivided } \\
\text { 2-lanes }\end{array}$ & 10.10 & - & $<0.5$ \\
\hline JL2 & $\begin{array}{l}\text { Divided 4- } \\
\text { lanes }\end{array}$ & 14.00 & 2 & $<0.5$ \\
\hline JL3 & $\begin{array}{l}\text { Divided 4- } \\
\text { lanes }\end{array}$ & 14.00 & 2 & $<0.5$ \\
\hline
\end{tabular}

\subsection{Traffic Volume Analysis}

Traffic volume analysis is used to analyze traffic characteristics to get daily traffic volume. Traffic volume is measured in a passenger car unit (vech). In this study, data collection began from Monday to Sunday in November 2020 on Roads JL1, JL2, and JL3 simultaneously by involving three groups of surveyors. The results of data analysis generated traffic volume, as shown in Figure 1.

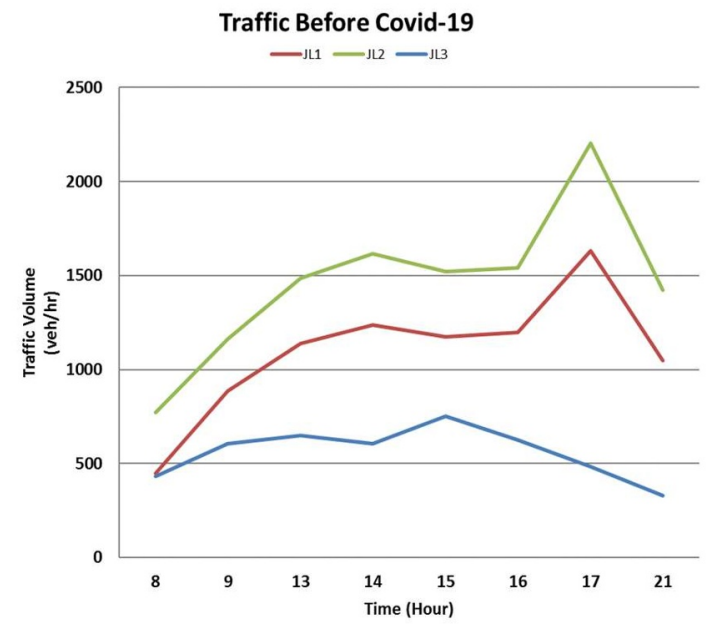

Fig.1. Traffic volume at peak volume hours before the COVID-19 pandemic

Figure 1 shows that the peak hour of traffic volume on Road JL2 at 16.00 - 17.00 before COVID-19 existed was $2202.7 \mathrm{vech} /$ hour. This road connects business centers in the city center of Ternate so that it becomes the main alternative chosen by most people in selecting routes from one business center to another. This road also connects the arterial road to the collector road which enters the business centers within the Galama business area. The traffic volume on Road JL2 had the same pattern as Road JL1. However, the traffic volume on Road JL1 was smaller. Meanwhile, Road JL3 was the road that had the lowest vehicle volume when compared to the other two roads.

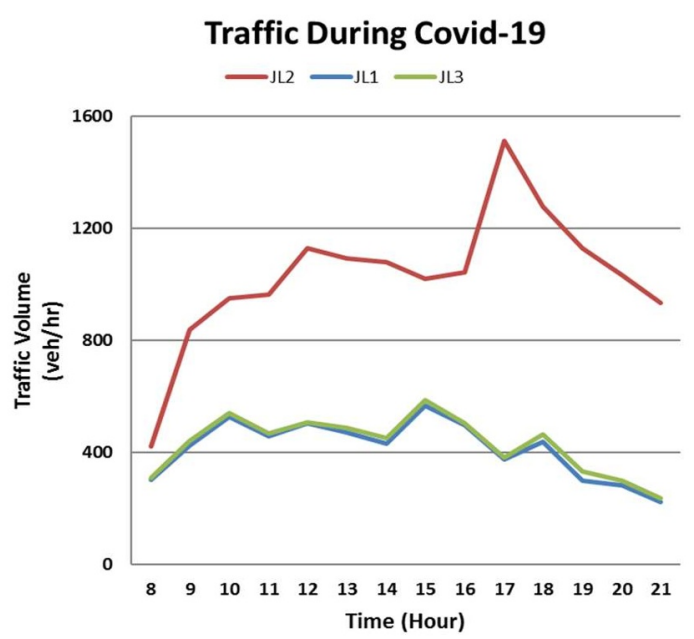

Fig. 2. Traffic volume at peak volume hours during the COVID-19 pandemic

Figure 2 shows the traffic volume during the COVID-19 pandemic. The largest traffic volume occurs on Road JL2. This shows that the policy of limiting activities during the COVID-19 pandemic does not change the burden and pattern of road users on the three roads being studied. Road JL2 still gets the biggest traffic load even though the volume has decreased when compared to that before the COVID-19 pandemic. The decrease in the volume of vehicles crossing Road JL1 is quite large, namely by $65 \%$. This indicates that the policy of working from home has a significant influence in reducing the number of people or vehicles moving from residential areas to business centers. Road JL2 experienced a decrease in traffic volume. However, it is only $31 \%$. This decrease is not as large as what happens in Road JL1. This is presumably caused by the number of offices in the business center so that employees or the business owners stay in their offices during the COVID19 pandemic. Meanwhile, Road JL3 has the smallest decrease, namely only $22 \%$. The peak hour of the traffic volume of the three roads reviewed does not change. The peak hour occurs at $16.00-17.00$, which is 1513.60 vech/hour on Road JL2.

\subsection{Road Capacity Analysis}

Capacity is the maximum traffic flow that can be maintained under certain conditions (geometric status, directional distribution, traffic composition, and environmental factors). Capacity is one of the factors to find out the DS value. The results of the analysis of the capacity of Roads JL1, JL2, and JL3 are presented in the following sections.

A. Road JL1

The basic capacity of the road is 1500 vech/hour/lane so that, for four lanes, it is 6000 vech /hour. Its road capacity adjustment is 0.92 , the directional split adjustment factor is 1 , the side friction adjustment factor is 0.84 , and the city size adjustment factor is 0.82 . Furthermore, the capacity of Road JL1 is $2515.45 \mathrm{vech} /$ hour. 
B. Road JL2

The basic capacity of the road is 2900 vech. Its road capacity adjustment is 1.29 , the directional split adjustment factor is 1 , the side friction adjustment factor is 0.82 , and the city size adjustment factor is 0.82 . Furthermore, the capacity of Road JL2 is $3802.2 \mathrm{vech} /$ hour.

C. Road JL3

The basic capacity of the road is 1500 $\mathrm{vech} /$ hour/lane so that, for four lanes, it is 6000 $\mathrm{vech} /$ hour. Its road capacity adjustment is 0.92 , the directional split adjustment factor is 1 , the side friction adjustment factor is 0.94 , and the city size adjustment factor is 0.82 . Furthermore, the capacity of Road JL3 is 4254.8 vech/hour.

\subsection{Degree of Saturation}

The degree of saturation (DS) is the ratio of traffic flow to the capacity of a certain road segment. The DS value can be used as a parameter to determine the level of road service. The DS value indicates whether a road segment has capacity problems.

Table 3. Degree of Saturation of Roads Under Study

\begin{tabular}{|c|c|c|}
\hline Roads & $\begin{array}{c}\text { Before the } \\
\text { Pandemic }\end{array}$ & $\begin{array}{c}\text { After the } \\
\text { Pandemic }\end{array}$ \\
\hline JL1 & 0.648 & 0.225 \\
\hline JL2 & 0.579 & 0.398 \\
\hline JL3 & 0.177 & 0.138 \\
\hline
\end{tabular}

\subsection{Level of Service}

The level of service (LOS) of the roads at business centers in the island area has changed due to the policy concerning the restrictions of the movement of road users. The LOS is one of the methods used to assess road performance and serves as an indicator for measuring congestion. A road can be categorized as experiencing congestion if the result of the LOS calculation is a value close to 1. Table 4 shows the level of service of examined roads before and during the COVID-19 pandemic.

Table 3. Level of Service of Roads Under Study

\begin{tabular}{|c|c|c|}
\hline Roads & $\begin{array}{c}\text { Before the } \\
\text { Pandemic }\end{array}$ & $\begin{array}{c}\text { After the } \\
\text { Pandemic }\end{array}$ \\
\hline JL1 & C & B \\
\hline JL2 & C & B \\
\hline JL3 & A & A \\
\hline
\end{tabular}

\section{Conclusion}

The results of the analysis concerning the level of service of roads in business centers in the island area indicate that the level of service of roads examined in this study has increased by one level during the COVID19 pandemic, specifically in Roads JL1 and JL2. Meanwhile, the Road JL3 does not experience a significant impact concerning the decrease in traffic volume as a result of the policy of the restrictions of the movement of road users during the COVID-19 pandemic.

\section{References}

1. S. Hanoatubun. Dampak Covid - 19 Terhadap Perekonomian Indonesia, EduPsyCouns Journal, Vol.2 No.1, hal. 146-153, (2020).

2. A Gaus, MA Sultan, IHA Wahab, AM Abdullah. Analysis of Service Levels of The Tidore-Sofifi Speedboat Mode During the COVID-19 Virus Pandemic, Journal of Physics: Conference Series 1899 (1), 012073, (2020).

3. I. Lestari. Analisis Tingkat Kepercayaan Dan Kepuasan Pelanggan Terhadap Niat Untuk Menggunakan Kembali Layanan Transportasi Online Di Era Pandemi Covid-19, Equilibrium Vol. 9. No. 1. Hal. 27-35, (2020).

4. D. Anggraeni. Dampak Pandemi Covid-19 Terhadap Sektor Moda Transportasi Darat (Bus Akap), Jurnal Indonesia Sosial Teknologi, Vol. 2, No. 7, hal. 1146-1154, (2021).

5. N. R. Yunus, A. Rezki. Kebijakan Pemberlakuan Lockdown Sebagai Antisipasi Penyebaran Corona Virus Covid-19. SALAM, Vol. 7 No. 3 Hal. 227238, (2020).

6. D. Indratmo. Kajian Kapasitas Jalan dan Derajat Kejenuhan Lalu-Lintas di Jalan Ahmad Yani Surabaya. Jurnal APLIKASI, Vol. 1, No. 1, Hal. 25-31, (2006).

7. A. Rizani. Evaluasi Kinerja Jalan Akibat Hambatan Samping (Studi Kasus Pada Jalan Soetoyo S Banjarmasin). PolhaSains, Vol. 1, No. 1, Hal. 1-8, (2013).

8. H. Fadriani, A. I. Syah. Pengaruh Pedagang Kaki Lima di Badan Jalan Terhadap Kecepatan dan Kapasitas Jalan. Isu Teknologi STT Mandala Vol.14, No.1 Hal. 1-7, (2019).

9. W. Ranto, A. L. E. Rumayar, J. A. Timboeleng. Analisa Kinerja Ruas Jalan Menggunakan Metode Manual Kapasitas Jalan Indonesia (MKJI) 1997. Jurnal Sipil Statik Vol.8 No.1 Hal. 77-82, (2020).

10. Alhani, Ko. Erwan, E. Sulandari Analisa Lalu Lintas Terhadap Kapasitas Jalan Di Pinggiran Kota Pontianak (Kasus Jalan Sungai Raya Dalam), JeLAST, Vol 4, No. 4, Hal. 1-7, (2017).

11. E. Kusnandar. Pengkinian Manual Kapasitas Jalan Indonesia 1997. Jurnal Jalan dan Jembatan, Vol. 26 No. 2, Hal. 1-11, (2009).

12. R. Syaputra, S. Sebayang, D. Herianto, Pengaruh Hambatan Samping Terhadap Kinerja Lalu Lintas Jalan Nasional (Studi Kasus Jalan Proklamator Raya - Pasar Bandarjaya Plaza). JRSDD, Vol. 3, No. 3, Hal. 441 - 454, (2015).

13. Departemen Pekerjaan Umum, 1997. Manual Kapasitas Jalan Indonesia (MKJI). Jakarta, Ditjen Bina Marga, 1997. 